\title{
Driven by Academic Norms and Status of Employment: The Advisory Roles of Political Scientists in Germany
}

\author{
Sonja Blum and Jens Jungblut
}

\subsection{INTRODUCTION}

While our knowledge of expertise brought into the policymaking field has increased significantly in recent years, there is still much to be learned about how the roles of experts and expertise vary from the comparative perspective, including across policy areas and fields of expertise. This chapter studies the policy advisory role played by Germany's political scientists. Germany represents an interesting case for several reasons. Traditionally, the focus has been on the consensus-seeking nature of Germany's 'civic epistemology' (Jasanoff, 2007), that is, the culturally specific practices of the State's production and use of knowledge (Straßheim \& Kettunen, 2014; see also Pattyn et al.,

\footnotetext{
S. Blum

FernUniversität in Hagen, Hagen, Germany

e-mail: sonja.blum@fernuni-hagen.de

J. Jungblut $(\bowtie)$

Department of Political Science, University of Oslo, Oslo, Norway

e-mail: j.p.w.jungblut@stv.uio.no

(C) The Author(s) 2022

M. Brans, A. Timmermans (eds.), The Advisory Roles of Political

Scientists in Europe, https://doi.org/10.1007/978-3-030-86005-9_8
} 
2019). Moreover, structural incentives for academics to engage in advisory work regarding political decision-making have been largely absent. However, mainly for historical reasons, German political science traditionally fulfils a 'watchdog' function, whereby it safeguards the democratic foundations of the State. Indeed, German political scientists have never been completely detached from societal debate or politics. At the same time, a strong academic ethos in Germany also limits policy advisory activities. Moreover, there may be differences in policy advisory activities between, for example, diverse levels of policymaking, policy sectors, and academic subdisciplines (such as public policy, electoral research, and political theory). In recent years, there has also been a lively debate among German political scientists regarding the political relevance of their discipline, which has gained momentum in the face of 'post-truth' and 'truthiness' discussions. Yet, while the debate is heating up, the role of political scientists in Germany's policy advisory system has not been the subject of much empirical research. ${ }^{1}$

Against this backdrop, this chapter studies how, to whom, and how often Germany's university-based political scientists provide their expertise for the purposes of policymaking. The analysis offered here is based on the German results of a survey of political scientists in more than 30 European countries that was conducted in the second half of 2018 and is presented in Chap. 2 of this book. The data provide the first systematic overview of the advisory activities, and the related views and incentives, of political scientists working at German universities. We substantiate the quantitative analysis with a case study that examines how Germany's political scientists' policy advisory activities play out with regard to a topical case, namely, how right-wing populism in parliaments and society can be understood and addressed.

\subsection{The German Policy Advisory System}

The policy advisory system in Germany, with regard to scientific policy advice, bas traditionally been correlated to the consensus-seeking nature of civic epistemology (Jasanoff, 2007; Straßheim \& Kettunen, 2014). In this, public knowledge-making is of a corporatist, institution-based character, and the main sources of expertise are authorized institutional

\footnotetext{
${ }^{1}$ To our knowledge that is with the exception of one study of the profession which included a question on policy advisory activities in a survey of German political scientists (Landfried, 1986).
} 
representatives, for example, trade unions and employers' organizations. However, research on policy advisory systems, particularly in the Englishspeaking world (Halligan, 1995), has revealed how processes of externalization have led to a general shift away from reliance on the public service sector to other providers of advice and to the professionalization of policy powers outside the public service realm. The nature of policy advice has also changed in the case of Germany (Veit et al., 2017). While there is a degree of continuity in consensus-seeking, there has been a process of pluralization and professionalization of the advisory landscape since the 1990s (Pattyn et al., 2019). Pluralization refers to the shift from a mainly vertical advisory system to a more horizontal one (Craft \& Howlett, 2013) characterized by the emergence of new, external advisory actors. In the German case, this has meant a weakening of the position of traditional advisory actors, the 're-discovery' of policy advice as a core task by nonuniversity research institutes (Thunert, 2013), and the emergence of new players. The process of professionalization, that is, the build-up of internal or external actors' powers to advise on different aspects of policy (Fobé et al., 2017), has seen the emergence of a 'consulting industry' (Heinze, 2013). The changes witnessed are correlated to the moving of parliament and almost all ministries from Bonn to Berlin and to the more competitive political climate of the 'Berlin Republic' (ibid.).

Overall, the policy advisory system in Germany currently seems more horizontal and pluralistic than vertical and hierarchical, although both types co-exist and interact, and the dominant one varies depending on the issue concerned and the specific context. The policy advisory structures depend on consensus-seeking, neo-corporatist traditions within a specific policy domain and on other factors such as whether long-term or anticipatory, more short-term or reactive decisions are concerned (see Craft \& Howlett, 2013). The strength of political scientists within departmental research (Ressortforschung) or on ministerial advisory councils also varies between policy sectors. Furthermore, advisory content also varies, with some matters being procedural, while others are more substantive (Craft \& Howlett, 2013; see also Prasser, 2006). As has been shown for other countries, the quantity, nature, and use of policy advice also depend on individual decision-makers in the political and administrative spheres (Landry et al., 2001). Policy sectors in Germany differ significantly with regard to the static characteristics of the advisory system, as well as in their dynamic characteristics (e.g. politicization, marketization of advice). These 
sectoral differences may also be reflected in the degree and type of involvement of political scientists.

\subsubsection{German Political Science and Policy Advice}

Germany has a large political science community, reflecting the established, advanced state of the discipline within academic research and teaching. As Schüttemeyer (2007, p. 183) concludes, political science 'is quite well positioned in the German university landscape'. While in some countries there has been a certain degree of specialization, in Germany all broader subdisciplines of political science have developed more or less equally. At the same time, as Eisfeld $(2019$, p. 182) warns, the considerable fragmentation of German political science may also endanger its overall political relevance. For political science, the relationship between 'politics' and 'science' as such is particularly pertinent and has been debated in Germany for decades (see, e.g. Landfried, 1986; cf. Blum \& Jungblut, 2020). More direct involvement in public debate and policymaking that goes beyond the mere provision of factual knowledge is still something that some regard with suspicion as being 'un-academic'. At the same time, at a fundamental level German academia sees itself as one of the watchdogs of German democracy (cf. Blum \& Schubert, 2013b), and this is also reflected in the fact that academic freedom is explicitly mentioned as one of the basic civil liberties by the German constitution. There is an historical reason for this: following the failure of academia during National Socialism, German political science was established (with significant support from the United States) as a discipline after WWII. Its defining feature was its status as a 'science for democracy' (Paulus, 2010). In their role as 'academic watchdogs', political scientists would defend the basic foundations of the democratic state, whilst at the same time maintaining a certain distance from day-to-day politics, partly in order to guarantee political independence. Thus, the role of political scientists in Germany may be described best by comparing them to referees that uphold the basic rules of the game but do not interfere with the way the game is actually played.

Recently, the debate regarding political scientists' societal role and involvement in policymaking has been rekindled (see the documentation of the German Political Science Association [DVPW] available at: https:// www.dvpw.de/informationen/debatte-zum-fach/). In April 2016, two political scientists writing in the daily newspaper FAZ claimed that 'the 
voice of political science is hardly heard any more in the public sphere, since debates are organised by lawyers and economists, while the younger generation remains silent' (own translation; Decker \& Jesse, 2016). In particular, the two authors criticized a self-referential, excessively fragmented nature of methodological and theoretical art for art's sake. The 'younger generation' did not remain silent for much longer after these claims were made but, on the contrary, responded with various articles published thereafter. Some of them (while disputing other points) generally agreed that German political science had been lacking in public visibility, while others (see Debus et al., 2017) argued that political science research does have impact. Furthermore, certain younger academics pointed to the low percentage of permanent posts in German academia and to the tough competition for such posts where policy advice is largely considered unimportant. Instead, the competition is often driven by a 'publish or perish' approach, by the awarding of grants, and to a large extent still by the traditional route of Habilitation. The 'habilitation' is characteristic of a handful of European countries, including Germany, and consists in the process of qualification for independent university teaching, said qualification being attained through a 'habilitation thesis' (traditionally the 'second book' a scholar publishes, but today often a series of published articles considered collectively) and a teaching exam.

To sum up then, there are limited incentives for younger scholars to become active in the policy advice field. The recent debate shows that the policy advisory role is one that German political scientists disagree on, in terms of both its desirability and the actual performance of the role. Although German political scientists' traditional removal from direct involvement with day-to-day politics may be changing, and German political scientists seem readier to 'get involved' in an advisory capacity, traditional values and the structure of the academic labour market in Germany are not conducive to such policy advisory activities.

\subsection{Expectations and Research Design}

Formulating expectations about the degree and types of policy advisory role played by political scientists in Germany is hampered by the fact that while the development of policy advice and the policy advisory system has been treated in the literature, the position of political science in relation to said system has not. However, we may draw some tentative assumptions from previous works on the state and development of political science in 
Germany, and of certain specific subfields thereof (Schüttemeyer, 2007; Blum \& Schubert, 2013a), as well as from the intense ongoing debate among German political scientists regarding the political relevance of their discipline.

The expectation is that all four ideal types of policy advisory role identified in Chap. 2 of this book can be recognized amongst German political scientists, albeit with significant differences in the presence of each ideal type. Given the specific traditions of German political science described above, we would expect the two prevailing types to be that of the pure academic and that of the expert. While the term 'pure academic' generally refers to those colleagues who avoid interacting, the term 'expert' includes those political scientists who are active in some policy advisory capacity, as a selected permanent or ad hoc advisor to ministries, agencies, political parties, parliaments, and so on. An expert may also be visible in the media, but with the main task of delivering facts and explaining political phenomena. The more fully opinionated scholar, who is more normatively oriented and outspoken about it, is expected to be rarer in Germany, to be found mainly among the older generation of professors. The widely active public intellectual is a role model that does not fit with German political science practices and is thus expected to be an exception.

Moreover, we expect there to be substantial differences between scholars with a permanent contract and those hired on a temporary basis, given the specifics of the German academic system, and in particular the limited number of permanent posts in German universities. Tenured posts in the German academic system are generally reserved for full professors, and very few other permanent positions exist, for example, those of lecturers. While a younger generation of political scientists in Germany may be readier to become involved in policy advisory activities, their temporary employment status may hinder this, in that career opportunities are still strongly based on academic core competencies and research performance and funding. Permanent staff (i.e. full professors in the main) would have greater opportunities to offer policy advice or engage in opinion making. In Germany, no real incentives exist for research communication or advice when pursuing an academic career. What this means is that those political scientists who engage in advisory activities must have other reasons for doing so other than their career advancement. 


\subsubsection{Research Design}

In the case of Germany, the survey questions used in this project were translated into German and only distributed in this language. ${ }^{2}$ A total of 376 of the 1986 political scientists, who were invited to participate in the survey in Germany, did so. This is a response rate of $18.9 \%$. The 1986 listed German political scientists are all employed at German universities. Of the respondents, $62 \%$ are employed on temporary contracts, while $32 \%$ are tenured; $26.8 \%$ of those who received the survey are professors and thus have a tenured post under the German university system (while a number of other tenured positions, e.g. as Akademischer Rat, are foreseen). Further, $64 \%$ of the respondents are male (this was only slightly less in the total population of political scientists who received the survey). Therefore, with regard to both the gender and contractual situations, our sample may be considered to be representative. The average age of respondents is 42 years. Furthermore, some $60 \%$ of the respondents hold a $\mathrm{PhD}$, around $14 \%$ has a 'habilitation', and about one quarter of them possess a master's degree and are often in the process of obtaining a PhD.

Based on the survey data, with the help of a simple descriptive analysis we shall offer an overview of the policy advisory activities of political scientists in Germany in general. In addition to a summary of the responses received to the survey, we shall also look at the important ongoing debate on the 'relevance' of German political science to the practice of policymaking. The survey responses also enable us to analyse the types and frequency of consultancy activities, the nature of the recipients and the governance level targeted, and also the channels through which advice flows. Secondly, we consider the patterns and contexts of the policy advisory roles of German political scientists and test the (tentative) expectations formulated earlier in this chapter. Finally, we discuss our findings by placing the patterns within the German context, and we evaluate what these findings may imply for the near future.

\footnotetext{
${ }^{2}$ We assumed this to be preferable to distributing the English-language survey, given the size of the German political science community, the importance of German as an academic language, and possible biases deriving from distributing an English-language survey particularly with a view to advisory and consultancy activities (i.e. those political scientists significantly engaged in advisory or consultancy work might specifically prefer to use German as their working language and be less inclined to answer a questionnaire written in English).
} 


\subsection{Empirical Patterns}

\subsubsection{Descriptive Results from the Survey}

From our data we can see that policy advice is typically given by German political scientists at least once a year, although some are more active, while a good number of them give advice less frequently or never at all. Those modes of advice giving used at least once a year include workshops and conferences, as well as face-to-face contact with actors/organizations (Table 8.1).

The most frequently used modes change somewhat if we look at the advisory activities of the more active political scientists, that is, those who provide advice once a month or even once a week; in their case, phone calls and emails are more important means of providing advice, which mirrors their more frequent exchanges with the advised policymakers or other actors. This may be because those giving advice on a more regular basis

Table 8.1 Modes of advice giving, in percentages-Germany

\begin{tabular}{|c|c|c|c|c|}
\hline & $\begin{array}{c}\text { Face-to-face with } \\
\text { the actor/ } \\
\text { organization }\end{array}$ & $\begin{array}{c}\text { Over the phone to } \\
\text { the actor/ } \\
\text { organization }\end{array}$ & $\begin{array}{c}\text { By email or post } \\
\text { to the actor/ } \\
\text { organization }\end{array}$ & $\begin{array}{c}\text { Via workshops or } \\
\text { conferences } \\
\text { (including events for } \\
\text { non-academic } \\
\text { audiences) }\end{array}$ \\
\hline $\begin{array}{l}\text { At least } \\
\text { once a } \\
\text { week }\end{array}$ & 1.0 & 0.7 & 1.3 & 0.3 \\
\hline $\begin{array}{l}\text { At least } \\
\text { once a } \\
\text { month }\end{array}$ & 5.9 & 4.9 & 6.2 & 7.5 \\
\hline $\begin{array}{l}\text { At least } \\
\text { once a year }\end{array}$ & 32.1 & 18.0 & 14.4 & 35.4 \\
\hline $\begin{array}{l}\text { Less } \\
\text { frequently }\end{array}$ & 16.1 & 14.8 & 14.4 & 12.8 \\
\hline Never & 10.8 & 23.0 & 23.3 & 10.5 \\
\hline $\begin{array}{l}\text { No } \\
\text { response }\end{array}$ & 34.1 & 38.7 & 40.3 & 33.4 \\
\hline Total & 100.0 & 100.0 & 100.0 & 100.0 \\
\hline
\end{tabular}

Source: ProSEPS survey data

Note: Question: 'Over the past three years, how frequently have you used any of the channels below to provide policy advice and/or consultancy services?' 
have already established a rapport and connection with the people that they advise, which means that their communications can go through less demanding, more flexible means such as emails or phone calls.

Besides providing information about the mode of policy advice provision, political scientists were also asked about the topics and frequency of the different forms of policy advice they had engaged in over the previous three years. The most commonly addressed topics were international relations and the EU (24.6\%), followed by government and public administration $(17.7 \%)$. Of the more specific public policy themes, civil and political rights were the ones most mentioned (14.1\%), followed by immigration (11.5\%). When looking at the different forms that policy advice can take, the most frequently found ones consist in evaluations of existing policies, and the analysing, and explaining the causes and consequences of policy problems. These are presented in Table 8.2.

We also calculated the bivariate correlations between the different forms of policy advisory activities and found highly significant and strong positive results for all of them; this would indicate that those who are active in one type of activity are also more likely to be active in one of the other types. Overall, the results show that there are a small number of political scientists in Germany who are very actively providing advice.

Political scientists were also asked how frequently, over the previous three years, they had used different channels to provide advice. The responses show that the most popular channels used by German political scientists to provide policy advice are still publications such as books and articles, which are used at least once a year by $37.4 \%$ of those responding, followed by research reports $(26.6 \%)$ and traditional media articles (18.7\%). Among the channels used at least once a month, blog entries $(3.9 \%)$ as well as training courses $(3.6 \%)$ score particularly high, which shows that a small, but active, percentage of German political scientists regularly engage in these rather specific advisory activities.

Political scientists not only reported the frequency and channels of their advisory activities but also to whom they provide their advice. The results are shown in Table 8.3. By far the most frequently advised types of actor are civil society organizations and citizens' groups, followed by political parties, think tanks, governmental politicians, and civil servants.

As regards the question of which policy levels are addressed by the advice of German political scientists, the survey shows that over the last three years more than a third of the German political scientists that engaged into advisory work did this mostly at a national or subnational 


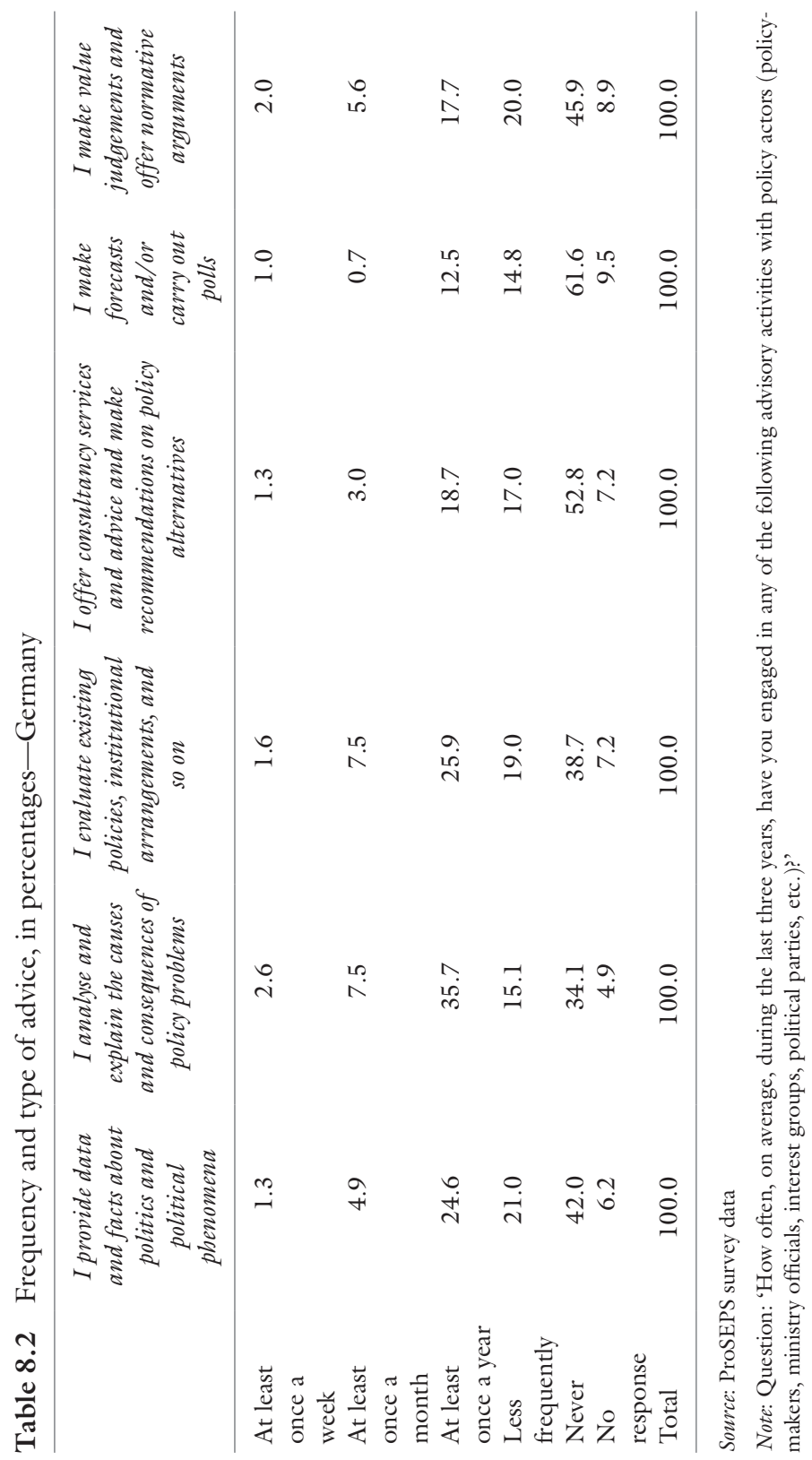


Table 8.3 Recipients of advisory activities, in percentages-Germany

\begin{tabular}{lc}
\hline Actors & $\%$ \\
\hline $\begin{array}{l}\text { Other civil society } \\
\text { organizations and citizen } \\
\text { group }\end{array}$ & 38.7 \\
Political parties & 28.5 \\
Think tanks & 26.6 \\
Governmental politicians & 25.9 \\
Civil servants & 24.3 \\
MPs & 19.0 \\
Advisory bodies & 16.1 \\
International organizations & 13.1 \\
Interest groups in private/ & 12.5 \\
corporate sector & \\
\hline
\end{tabular}

Source: ProSEPS survey data

Note: Question: 'With which actors have you engaged in knowledge exchange, advisory or consulting activities over the last three years?'

level. Advisory activities at the subnational level may be encouraged in Germany by the federal structure of the state. Advice is more seldom provided to the EU or to actors on the international stage. The fact that Germany is a prominent and powerful EU member state is only clear to some extent in the level of advising. This mostly concerns a small, specialized group of political scientists.

When asked about the agreement of respondents with normative statements on the role of political scientists as policy advisors, the results displayed in Table 8.4 show the strongest level of agreement with the statement that political scientists should engage in public debate since this is part of their role as social scientists. This indicates that most political scientists in Germany are in favour of some form of engagement.

\subsubsection{Factors Influencing Policy Advisory Activities}

Given the nature of the German academic labour market, with only about $17 \%$ of academics (across all disciplines) holding a permanent position, and with the pressure on those in temporary employment to perform in a way that may help them secure a permanent position at some point, we expect the difference in employment status to have an impact on the 
Table 8.4 Normative views on policy advice, in percentages-Germany

\begin{tabular}{lccc}
\hline & $\begin{array}{c}\text { Political scientists } \\
\text { should engage in } \\
\text { public debate since this } \\
\text { is part of their role as } \\
\text { social scientists }\end{array}$ & $\begin{array}{c}\text { Political scientists } \\
\text { should engage in public } \\
\text { debate because this helps } \\
\text { them to expand their } \\
\text { career options }\end{array}$ & $\begin{array}{c}\text { Political scientists should } \\
\text { advisory activities only after } \\
\text { testing their ideas in } \\
\text { academic outlets }\end{array}$ \\
\hline $\begin{array}{l}\text { Fully agree } \\
\text { Somewhat } \\
\text { agree }\end{array}$ & 50.8 & 5.6 & 19.3 \\
$\begin{array}{l}\text { Somewhat } \\
\text { disagree }\end{array}$ & 42.3 & 29.2 & 38.4 \\
$\begin{array}{l}\text { Fully } \\
\text { disagree }\end{array}$ & 4.3 & 41.3 & 23.9 \\
$\begin{array}{l}\text { No } \\
\text { response }\end{array}$ & 1.6 & 16.4 & 13.4 \\
Total & 1.0 & 7.5 & 4.9 \\
\hline
\end{tabular}

Source: ProSEPS survey data

Note: Question: 'To what extent do you agree with the following statements?'

policy advisory activities undertaken. Based on histograms depicting the difference between the two groups, it becomes clear that the two samples are non-normally distributed with regard to the outcome variable. Thus, to test whether the two groups differ in their mean responses regarding their policy advisory activities, we use Mann-Whitney tests (Mann \& Whitney, 1947). ${ }^{3}$ Consequently, the differences detected with these unequal group sizes offer especially valuable insights. We filtered out those respondents who had a missing value in the variable assessing their contractual situation, resulting in a sample size of 354 (22 missing values).

With regard to the frequency with which different types of policy advice are provided, we found significant differences for five of the six types of advice. Respondents with tenure indicated that they more frequently analyse and explain the causes and consequences of policy problems ( median $=3$ vs. median $=4$; lower values represent more regular activity; $U=6618$; $z=-4.161 ; p<0.001 ; r=-0.221)$, evaluate existing policies or

${ }^{3}$ While we have an unequal sample size (just under two-thirds of the respondents are employed on temporary contracts), this is no problem with regard to the applicability of Mann-Whitney tests, although it is important to bear in mind that the statistical power (i.e. the ability to detect a difference that is also present in the population) will diminish as the group sizes become increasingly unequal. 
institutional arrangements (median $=4$ vs. median $=5$; lower values represent more regular activity; $U=7001.5 ; z=-3.547 ; p<0.001 ; r=-0.188$ ), and offer consultancy or advice regarding recommendations on policy alternatives $($ median $=4$ vs. median $=5$; lower values represent more regular activity; $U=6697.5 ; z=-4.216 ; p<0.001 ; r=-0.224)$. Moreover, those respondents with tenure also more frequently make value judgements and present normative arguments (median $=4$ vs. median $=5$; lower values represent more regular activity; $U=7650 ; z=-2.579$; $p<0.01 ; r=-0.137)$ and provide data and facts about politics and political phenomena $($ median $=4$ vs. median $=5$; lower values represent more regular activity; $U=7823.5 ; z=-2.275 ; p<0.023 ; r=-0.120)$. To sum up, this part of the analysis shows that, as we would expect, German political scientists with tenured positions are more active in providing policy advice.

\subsubsection{Ideal Types of Policy Advisory Role}

Based on the operationalization of the ideal types of policy advisory role (see Chap. 3), we investigated the number of German respondents falling into one of the ideal categories and compared the division of German political scientists with the overall sample (see Table 8.5).

The results show that most political scientists in Germany provide some form of policy advice and that the largest group also makes at least some form of normative or value judgement when doing so. Both of these results tend to confound our expectation that the two most prominent ideal types in Germany are the pure academic and the expert, particularly those who do not make normative assessments. At the same time, German

Table 8.5 Proportions of advisory roles-Germany

\begin{tabular}{lccc}
\hline Ideal type & $\begin{array}{c}\text { Total number in } \\
\text { Germany }\end{array}$ & $\begin{array}{c}\text { Percentage in } \\
\text { Germany }\end{array}$ & $\begin{array}{c}\text { Percentage in overall } \\
\text { sample }\end{array}$ \\
\hline Pure academic & 112 & $29.8 \%$ & $20.3 \%$ \\
Expert & 94 & $24.9 \%$ & $26.6 \%$ \\
Opinionating & 155 & $41.3 \%$ & $48.7 \%$ \\
scholar & 15 & $3.9 \%$ & $4.4 \%$ \\
Public intellectual & & & \\
\hline
\end{tabular}

Source: Author

Note: Types operationalized on the basis of the content and frequency of advice 
political scientists are more often linked to the pure academic type than on average considering all the countries concerned. Thus, when looking at the findings from a comparative perspective, our expectations for Germany are to some extent substantiated. Nonetheless, in general it appears that the level of political scientists' policy advisory activity is higher than was initially thought considering Germany's academic context.

Cross-tabulating the ideal types by their highest level of academic quantification, Table 8.6 clearly shows that scholars performing policy advisory activities are more often the ones with a $\mathrm{PhD}$. Although most pure academics have a $\mathrm{PhD}$, the possession of such an academic qualification is much more pronounced in the case of the other role types. This lends support to our belief that policy advisory activity is influenced by academic credentials, which also correlates positively with having a permanent position within the German academic system. A small group of scholars who do not yet possess a PhD also engages in the provision of policy advice.

When looking at gender distribution across the four ideal types, Table 8.7 shows that male scholars represent the majority of those more active in policy advice provision. As policy advisory activities become exposed to a wider audience, the gender gap becomes more pronounced. While other factors may also be relevant here, such as the lower percentage of female academics with tenure, this gender gap may indicate a bias towards men in the policy advisory activities of German political scientists. This in turn may be related to the extent to which research agendas in Germany are gendered (Key \& Sumner, 2019) and to the implications of this in terms of the demand for knowledge and policy advice.

Finally, since we expected, and indeed found, that a main factor in policy advisory activity is the type of academic position, we also cross-tabulated the contract variable with the ideal type of role. Table 8.8 presents an overview of the relationship between the two.

Table 8.6 Highest university degree by advisory role—Germany

\begin{tabular}{lcccc}
\hline & $\begin{array}{c}\text { Pure } \\
\text { academic }\end{array}$ & $\begin{array}{c}\text { Pure } \\
\text { expert }\end{array}$ & $\begin{array}{c}\text { Opinionating } \\
\text { scholar }\end{array}$ & $\begin{array}{c}\text { Public } \\
\text { intellectual }\end{array}$ \\
\hline $\begin{array}{l}\text { MA degree or } \\
\text { equivalent }\end{array}$ & $43.2 \%$ & $22.8 \%$ & $15.0 \%$ & $14.3 \%$ \\
$\begin{array}{l}\text { PhD or habilitation } \\
\text { Total }\end{array}$ & $56.8 \%$ & $77.2 \%$ & $85.0 \%$ & $85.7 \%$ \\
\hline
\end{tabular}

Source: ProSEPS survey data 
Table 8.7 Advisory roles by gender-Germany

\begin{tabular}{lcccc}
\hline & Pure academic & Expert & Opinionating scholar & Public intellectual \\
\hline Female & $44.4 \%$ & $32.6 \%$ & $27.5 \%$ & $14.3 \%$ \\
Male & $55.6 \%$ & $67.4 \%$ & $72.5 \%$ & $85.7 \%$ \\
\hline
\end{tabular}

Source: Author

Table 8.8 Advice roles by type of academic position (percentages by position)-Germany

\begin{tabular}{lccc}
\hline Ideal type & $\begin{array}{c}\text { Non-permanent } \\
\text { contract }\end{array}$ & $\begin{array}{c}\text { Permanent } \\
\text { contract }\end{array}$ & No response \\
\hline Pure academic & $37.6 \%(88)$ & $19.0 \%(23)$ & $4.5 \%(1)$ \\
Pure expert & $25.2 \%(59)$ & $25.6 \%(31)$ & $18.2 \%(4)$ \\
Opinionating scholar & $33.3 \%(78)$ & $51.2 \%(62)$ & $72.7 \%(16)$ \\
(expert + value judgements) & & & \\
Public intellectual & $3.8 \%(9)$ & $4.1 \%(5)$ & $4.5 \%(1)$ \\
Total & $100 \%(234)$ & $100 \%(121)$ & $100 \%(22)$ \\
\hline
\end{tabular}

Source: ProSEPS survey data

The cross-tabulation outcome confirms our expectation that the contractual situation of German political scientists will influence their policy advisory activities, since most pure academics in the German sample are on temporary contracts, while pure academics represent the largest category of political scientists on temporary contracts.

Given our aforementioned finding that male respondents and those with a higher academic degree are more frequently among the active ideal types, we calculated Cramer's $V$ for the correlation between the academic position and the gender of the respondents. Both correlations were highly significant at $p<0.001$, and as expected, the correlation between academic degree and position is strong $(0.50)$, while the correlation between position and gender is of a medium effect size (0.32). Thus, gender, academic position, and highest academic degree all represent interrelated factors influencing the extent of policy advisory activity.

Given that the four role types can be understood to range from the pure academic, as the least active type, to the public intellectual as the most active type, with regard to advisory activities, and since we can also assume the directionally of the relationship, in the sense that the type of 
position influences the ideal type of policy advisory role, we conducted a Mann-Whitney test to establish the significance of this relation. The results show that respondents with tenure are significantly more likely to have a higher level of policy advisory activity (median $=2 \mathrm{vs}$. median $=1$; higher values represent more policy advisory activity; $U=7205.5 ; z=-3.265$; $p<0.001 ; r=-0.174)$. However, the effect size of the relationship is small.

In sum, the analysis of the distribution of ideal types of policy advisory activity has shown that overall, German political scientists are less active in the provision of policy advice than the average European political scientist. At the same time, a larger number than expected provide some form of policy advice, including normative judgements. The most frequent role type in relative terms is that of the opinionating scholar. Finally, male respondents with 'higher' academic credentials and a permanent contract are more likely to engage in publicly visible advising and opinionating.

\subsection{A Case Study of Advice on the Rise of Populism}

To further substantiate the quantitative analysis with an illustrative case study, we have drawn on the case of how the rise of right-wing populism in parliament and society is to be addressed. This represents a 'very likely case' of the engagement of German political scientists in real-world policymaking and also an opportunity for them to exercise various policy advisory activities. Regardless of whether or not one shares his views on the relevance of political science, this is confirmed by the political scientist Eckhard Jesse when he writes that:

Academic disciplines such as political science and sociology have, due to their strong self-referentiality, have seen their reputation impaired; however, with the Pegida-phenomenon-probably the first new German right-wing social movement since Nazism-they have become highly topical. ${ }^{4}$ (FAZ, 4 January 2017)

To track policy advisory activities more systematically within this context, we focus on how political scientists have contributed to the debate and presented their research findings, in the form of articles published in two leading German quality newspapers: the Süddeutsche Zeitung (SZ) and

${ }^{4}$ All quotes from newspaper articles within this chapter are own translations. 
the Frankfurter Allgemeine Zeitung (FAZ). Although this admittedly excludes many key policy advisory activities from the picture (e.g. informal talks), it enables certain activities (policy advice through media articles) to be systematically tracked and others (e.g. 'popular science' books written by political scientists) to be hinted at. The focus here is on the period 2015-2017, which was one of key developments for the specific German case. In late 2014, the right-wing political movement Pegida (Patriotic Europeans against the Islamisation of the Occident) was founded in Dresden, and from early 2015 on it attracted increasing public attention. The most visible developments were Pegida's weekly demonstrations gathering up to 20,000 demonstrators in Dresden, held on Monday evenings over the course of 2015 and at the height of the so-called refugee crisis in the summer and autumn of that year. The year 2017 saw the runup to the German federal elections held in September 2017, at which the right-wing AfD (Alternative for Germany) obtained seats for the first time in the Bundestag. The AfD took $12.6 \%$ of the votes, coming third behind the conservative CDU/CSU and the social-democratic SPD.

What policy advice from Germany's political scientists do we find in the newspapers during those years, and how does this relate to the results of our survey? Overall, political scientists participated, and continue to participate, in the discussion. The FAZ published eighteen articles written by political scientists over the course of the three years in question; these articles included analyses, commentaries, and discussions regarding new books on populism and other related topics. In the SZ, political scientists wrote eleven articles in total. Moreover, the SZ published two interviews with political scientists, while the FAZ published four. Furthermore, political scientists were cited in several other articles-either in the form of direct quotes (often after they had been interviewed) or by citing definitions or terms from political science research on populism and related topics. We focus here on direct contributions, as these show a clear intention to provide analysis and advice for the purposes of policymaking. Newspaper articles imply that political scientists are reaching out, and offering their opinions and advice, to the reading public.

Almost all of the writers in question were men (we found only two articles in FAZ and one in SZ, written by female political scientists, the latter co-authored with a male scholar). This example confirms the gender bias found in the survey analysis presented earlier. In the case of the FAZ, certain political scientists have contributed two or more articles, while two have written articles for both newspapers. The content of these articles is 
closest to the opinionating ideal type role or, when visibility and effects are high, to the role of public intellectual. Orientation is also of a partly generational nature. Overall, the vast majority of political scientists contributing one or more articles are university professors, who may be invited to contribute more frequently.

Overall, there seems to be either little demand for, or little desire on the part of, political scientists to present the results of concrete studies or projects; the focus is mostly on broader expertise and analysis. If concrete publications are addressed, they tend to concern highly influential books. There is one clear exception to this rule, namely, the earliest studies of the Pegida movement. For example, a lengthy article appeared in the FAZ in October 2015 ('What is Pegida and why?'), in which three political scientists from Dresden presented the findings of their study of Pegida (which were presented in even more concrete terms in other articles written by journalists: see, e.g. the SZ of 15 January 2015). In terms of our categories of advisory activity, the provision of data and facts is accompanied by analysis of causes, and then the authors move on to offering forecasts of the likely outcome of events:

\begin{abstract}
About one third of the participants of the demonstration and 'evening strolls' showed diffuse Anti-Islam motives and attitudes. The majority passed fundamental criticism of politics, media and the practiced modes of democracy. $[\ldots]$ Pegida may be interpreted as a protest against $[\ldots]$ a political order, in which economic power and public-administrative functional elites prepare political decisions, but depart from the experiences of citizens and what may democratic-legitimatory be assigned to them [...]. In a few years, the movement may be interpreted as a harbinger of political-cultural conflicts and interpretative battles about identities in an immigration society. [...] It seems that German democracy is facing a severe test. (FAZ, 19 October 2015)
\end{abstract}

During the course of 2016 and 2017 in particular, following the further rise of right-wing populism, more 'opinionated' or engaged contributions on populism, the state of democracy, and recommended courses of action appeared. For example, the following article offers an in-depth analysis of the problems of democracy-based on numbers taken from opinion polls and from the (political theory) research literature (i.e. explanation of causes) - which led to more normative judgements and (broad) policy advice as well: 
We have to think much more about the procedures and institutions, with which minorities may legitimately complain about their disrespect, without having to use "the people" for this. [...] And finally, we have to think about how our electoral law, but also the interdependencies of central state and federal state policymaking can be designed in such a way that disputes and conflicts seem not only as barriers on the way to a decision 'shared by everyone'. But that rather these conflicts are acknowledged as a legitimate form of governing, in the same way as agreement and compromise. It is high time to start thinking about this. Because defending democracy in times of disappointment begins with ourselves. (SZ, 25 July 2017)

Overall, the question of the rise of right-wing populism would appear to have led political scientists from different subdisciplines not only to provide their expertise on the matter in the form of 'facts' and analysis but also to make more normative judgements in the sense of their becoming politically engaged in favour of democracy. In the specific medium we have looked at here, it is still somewhat surprising to see how the discourse reflects limited differences in participation in the provision of policy advice, in terms of political scientists' academic positions, gender, and cultural background. The question remains as to whether this is more a question of supply or of demand.

\subsection{Conclusion: Tenured Academics in a Castle? Advisory Roles in Germany}

This analysis provides a first empirical account of the policy advisory activities of German political scientists. In doing so, it not only provides empirical insight into a seldom studied phenomenon but also aims to further the intense debate among German political scientists regarding the political and social relevance of today's political science. In general, advising on policy is something that political scientists in Germany appear to be engaged in to a greater degree than expected given the German academic context. While they are less active than their other European counterparts, as shown by the broad survey results, the most commonly found ideal type of German political scientist is the opinionating scholar, followed by the pure academic, the expert, and finally, as in all countries, the public intellectual. This is contrary to our initial expectations, even though Germany has a higher proportion of pure academics than the overall sample's 
average. It may be because German political scientists are constrained by greater internal or external limits when engaging in advisory activities.

This would seem to be corroborated by the fact that German political scientists do not provide their advice very often, typically 'at least once a year' according to our respondents. Some colleagues are more active than this, but a larger percentage of political scientists give advice less than once per year, or indeed never at all. The more active forms of advising include workshops, conferences, and face-to-face contact with actors/organizations. The preferred means of conveying advice, however, is through books, articles, and research reports and, limited to a smaller group, also traditional media articles. Together with active outreach work, traditional academic outlets thus remain central to the advisory work of political scientists.

Over $90 \%$ of German political scientists agreed to an extent with the statement that 'Political scientists should engage in public debate since this is part of their role as social scientists'. This indicates that even if they still rely very much on traditional methods of knowledge divulgation, German political scientists nevertheless believe that engaging with the public is an important part of their work. Whether it is valued in terms of their academic career-prospects, however, is another question.

An examination of conditional factors within the sample of political scientists reveals that contract status has a major impact on the way that policy advisory activities are perceived and performed. German political scientists with tenure are generally more active in the field of policy advising. Academic qualifications and gender also make a difference: male respondents are much more represented in the more active role types, while possession of a $\mathrm{PhD}$ also seems to open the way for an advisory role, with this category of scholar likely to be more involved in providing advice than those still in the process of obtaining their $\mathrm{PhD}$. Given the highly stratified and competitive nature of the German academic labour market, these findings are not surprising as they indicate that scholars without a permanent position do not have the standing or opportunities to engage in policy advising, since they are more focused on the core academic activities they are required to engage in to obtain a permanent post.

The case of German political scientists giving advice, through the media, on rising populism in parliament and society, confirms the survey findings. Firstly, political scientists played an active part in this debate in the traditional media between 2015 and 2017. Secondly, their contributions in the media included a variety of policy advisory activities-from the 
provision of data and facts, and the analysis of causes, consequences, and forecast future developments, to more normative statements, positiontaking, and recommendations. Thirdly, those political scientists contributing their own articles in the traditional media are mainly tenured professors and also mostly male.

Our analysis, based on the combination of the survey findings and the case study, draws a mixed picture of the policy advisory activities of political scientists in Germany. There is a higher than expected level of general activity and of acceptance of policy advisory work, with the contractual situation appearing as a key factor in this engagement. One conclusion we can draw from this is that the recurring complaint of German political scientists' lack of societal interaction and relevance does not appear entirely justified (see also Blum \& Jungblut, 2020). Eisfeld's call (2019, p. 190) for the transformation of political science in Germany to a 'relevant, citizen-oriented science of democracy' may still have some way to go before achieving its objective. However, given the findings presented in this chapter, it is important to realize that such a transformation will not come about if it is only based on a strict 'impact agenda' that reduces the freedom to choose between different, or even complementary, roles such as the pure academic, the expert, the opinionating scholar, and/or the public intellectual. The analysis presented here is but a first explorative assessment of the issue, and further research is very much needed to unbundle the policy advisory roles of political scientists in Germany. Such further analysis, exploring in greater depth cases of policy advisory work as well as engaging in more quantitative work covering a broader sample of political scientists, perhaps also compared to other disciplines, will further our understanding of the emerging arenas of policy advice in which scholars are involved. Moreover, such future research should include not only the supply side of knowledge production and advice provision but also the demand side by investigating the way in which recipients and users of advice perceive, and can develop, the roles played by political scientists in Germany's policy advisory system.

\section{REFERENCES}

Blum, S., \& Jungblut, J. (2020). Besondere Freiheit, besondere Verantwortung? Eine empirische Studie zur deutschen Politikwissenschaft in der Politikberatung. dms - der moderne staat - Zeitschrift für Public Policy, Recht und Management, $13(2), 486-506$. 
Blum, S., \& Schubert, K. (Eds.). (2013a). Policy analysis in Germany. The Policy Press.

Blum, S., \& Schubert, K. (2013b). Policy analysis in Germany: Past, present, and future of the discipline. In S. Blum \& K. Schubert (Eds.), Policy analysis in Germany (pp. 1-17). The Policy Press.

Craft, J., \& Howlett, M. (2013). The dual dynamics of policy advisory systems: The impact of externalization and politicization on policy advice. Policy and Society, 32, 187-197.

Debus, M., Faas, T., \& Schäfer, A. (2017). Einfluss auf Debatten. Ist die Politikwissenschaft irrelevant? FAZ, May 17. https://www.faz.net/aktuell/ politik/inland/einfluss-auf-debatten-ist-die-politikwissenschaftirrelevant-15019746.html

Decker, F., \& Jesse, E. (2016). Lage der Politikwissenschaft. Fach ohne Ausstrahlung. FAZ, April 20. https://www.faz.net/aktuell/feuilleton/ forschung-und-lehre/politikwissenschaft-und-ihre-lage-der-in-deroeffentlichkeit-14186054.html

Eisfeld, R. (2019). Empowering citizens, engaging the public. Political science for the 21st century. Palgrave Macmillan.

Fobé, E., De Peuter, B., Petit Jean, M., et al. (2017). Analytical techniques in Belgian policy analysis. In M. Brans \& D. Aubin (Eds.), Policy analysis in Belgium (pp. 151-170). Policy Press.

Halligan, J. (1995). Policy advice and the public sector. In G. B. Peters \& D. T. Savoie (Eds.), Governance in a changing environment (pp. 138-172). McGill-Queen's University Press.

Heinze, R. G. (2013). Federal Government in Germany: Temporary, issue-related policy advice. In S. Blum \& K. Schubert (Eds.), Policy analysis in Germany (pp. 135-148). Policy Press.

Jasanoff, S. (2007). Designs on nature. Science and democracy in Europe and the United States. Princeton University Press.

Key, E., \& Sumner, J. L. (2019). You research like a girl: Gendered research agenda and their implications. PS: Political Science and Politics, 52(4), 663-668.

Landfried, C. (1986). Politikwissenschaft und Politikberatung. In K. von Beyme (Ed.), Politikwissenschaft in der Bundesrepublik Deutschland (Politische Vierteljahresschrift). VS Verlag für Sozialwissenschaften.

Landry, R., Amara, N., \& Lamari, M. (2001). Utilization of social science research knowledge in Canada. Research Policy, 30, 333-349.

Mann, H. B., \& Whitney, D. R. (1947). On a test of whether one of two random variables is Stochastically larger than the other. The Annals of Mathematical Statistics, 18(1), 50-60.

Pattyn, V., Blum, S., Fobé, E., Pekar-Milicevic, M., \& Brans, M. (2019). Academic policy advice in consensus-seeking countries: The cases of Belgium and 
Germany. International Review of Administrative Sciences. https://doi. org/10.1177/0020852319878780

Paulus, S. (2010). Vorbild USA? Amerikanisierung von Universität und Wissenschaft in Westdeutschland, 1945-1976. Oldenbourg.

Prasser, S. (2006). Providing advice to government. Papers on Parliament. Canberra: Senate of Australia. http://www.aph.gov.au/senate/pubs/pops/ pop.46/providing_advice.htm

Schüttemeyer, S. (2007). The current state of political science in Germany. In H. D. Klingemann (Ed.), The state of political science in Western Europe. Barbara Budrich Publishers.

Straßheim, H., \& Kettunen, P. (2014). When does evidence-based policy turn into policy-based evidence? Configurations, contexts and mechanisms. Evidence \& Policy, 10(2), 259-277.

Thunert, M. (2013). Non-university research institutes: Between basic research, knowledge transfer to the public and policy analysis. In S. Blum \& K. Schubert (Eds.), Policy analysis in Germany (pp. 247-264). Policy Press.

Veit, S., Hustedt, T., \& Bach, T. (2017). Dynamics of change in internal policy advisory systems: The hybridization of advisory capacities in Germany. Policy Sciences, 50, 85-103.

\section{SOURCES}

FAZ. (2015 October 19). Authors H. Vorländer, M. Herold, \& S. Schäller. Was ist Pegida und warum?

FAZ. (2017, January 4). Author E. Jesse. Orientierunglose Enttäuschte? Die Dresdner Pegida-Protestbewegung wird vielfältig durchleuchtet.

SZ. (2015, January 15). Die Mittelschicht marschiert. Eine Studie untersucht erstmals die Pegida-Bewegung.

SZ. (2017, July 25). Author A. Brodocz. Wir erwarten zu viel von der Demokratie. Oder zumindest das Falsche. Anders lässt sich nicht erklären, warum so viele von ihr enttäuscht sind. Eine Verteidigung. 
Open Access This chapter is licensed under the terms of the Creative Commons Attribution 4.0 International License (http://creativecommons.org/licenses/ by $/ 4.0 /$ ), which permits use, sharing, adaptation, distribution and reproduction in any medium or format, as long as you give appropriate credit to the original author(s) and the source, provide a link to the Creative Commons licence and indicate if changes were made.

The images or other third party material in this chapter are included in the chapter's Creative Commons licence, unless indicated otherwise in a credit line to the material. If material is not included in the chapter's Creative Commons licence and your intended use is not permitted by statutory regulation or exceeds the permitted use, you will need to obtain permission directly from the copyright holder. 